\title{
Crisis in the Québec forest industry: problems and possible solutions
}

\author{
by Robert Beauregard ${ }^{1}$ and Luc Bouthillier ${ }^{2}$
}

Despite the revival of the past months, the forest industry in Québec has gone through very rough times since the beginning of the nineties. These serious difficulties cannot only be attributed to a worldwide economic recession. They also reflect a deep structural crisis particular to this industry. Evolving on a global commondity market without a clear competing edge, Québec forest industry requires a colossal modernization effort. This effort should not be applied only to machinery but also to the management strategies which firms are pursuing. Better targeted markets, increased environmental concerns, renewed partnership with workers and restructuring schemes defined accordingly to a full employment policy represent ideas which must be translated in tangible initiatives to get out of the crisis.

During the past few years, the forest industry in Québec has been living a nightmare. The industry is suffering from gangrene. Yet, since the 1920's, the forest industry has gone through many ups and downs, and more ups than downs. The present crisis, however, appears deeper than a simple downwards trend in a normal economic cycle. It is apparent that the difficulties of Cascades in Port-Cartier and Donohue in Matane, or the closing of Canadian Pacific Forest Products (CPFP) in Trois-Rivières are symptoms of a major upheaval. It's easy to believe that after the present crisis, the industry will never be the same.

This paper presents a brief explanation of the causes of this crisis (investments, costs, markets, political problems), followed by an overview of the possible solutions to these problems.

\section{Chronic Under-investment}

It is well known that an industry that wants to have healthy development must invest. A study by Price Waterhouse for the Forest Sector Advisory Council of Canada ${ }^{3}$ compares the performances of the commerical pulp and paper industry in eastern Canada with those of British Columbia, the southern and western United States, Sweden and Finland. This study showed that between 1985 and 1989, the industrialists in eastern Canada invested $\$ 72$ per ton of pulp produced, compared with $\$ 186$ in Sweden, \$212 in the southern United States, \$502, in Finland and \$541 in British Columbia.

This indication of under-investment in Québec seems to be confirmed by a recent study by Léo-Paul Lauzon, professor in accounting science at the University of Québec in Montreal. Professor Lauzon studied Canadian Pacific Forest Products Limited between the years 1986 and $1989^{4}$

\footnotetext{
${ }^{\mathrm{I}} \mathrm{Ph}$.D. student in Wood Sciences at Laval University.

${ }^{2}$ Adjunct professor in Forest Policy at Laval University.

${ }^{3}$ The market pulp industry 1985-1989 study done for the Forest Sector Advisory Council, Price Waterhouse, October 1990, p. 33.
}

Malgré le regain des derniers mois, l'industrie forestière du Québec éprouve de graves difficultés depuis le début de la décennie 1990. Celles-ci résultent non seulement d'une mauvaise conjoncture économique, mais aussi des manifestations d'une crise structurelle profonde qui est propre à cette industrie. Évoluant sur un marché mondial dans une gamme de produits standardisés sans disposer d'un avantage comparatif évident, un effort colossal de modernisation s'impose à l'industrie forestière. L'effort requis ne s'applique pas uniquement aux machines dans les usines. Les modes de gestion des entreprises sont également en cause. Des marchés mieux identifiés, une préoccupation environnementale accrue, une réelle implication des travailleurs dans la gouverne des affaires et un redéploiement de l'industrie dans une optique de plein emploi représentent autant d'idées à traduire en actions concrètes pour sortir de la crise.
Lauzon found that during this period, the dividends paid to stockholders increased from 23 million dollars in 1987 to 114 million in 1989 , which is a $400 \%$ increase. In 1989 , the directors decided to increase dividends in spite of the fact that the net profit had diminished considerably. He noticed as well that CPFP invested less than $0.3 \%$ of sales revenues for research and development during the 1980s, in spite of many available governmental programs to support research. Finally, he showed that the Québec factories were almost completely excluded from the company's investment projects. The closing of the plant at Trois-Rivières announced in January 1992 must be placed in this context.

It is no exaggeration to say that, in general, the pulp and paper industry in Québec rested on its laurels. While the amount of investment during the past 10 years reached nearly nine billion dollars, it should be noted that more than $40 \%$ of the production capacity of the industry had been built before 1935. Moreover, it must be mentioned that around fifteen paper machines have been installed in the United States in the last few years. Consequently, whereas in 1980 , the American industry satisfied close to $38 \%$ of its domestic newsprint consumption, 10 years later, it fulfills nearly $50 \%$ of its internal needs. Canada and Québec now find themselves in the position of being surplus suppliers.

This situation is made even more uncomfortable because it is evident that a machine built in the 1920's, producing 40,000 to 60,000 tons of newsprint per year, requiring more than 1,000 employees cannot compete with a plant of the 1990 's producing 250,000 tons with 500 employees and a minimal quantity of effluent.

This is a main point of the problem of the pulp and paper industry in Québec. The industry is outdated in spite of the modernization program at the beginning of the 1980's. This program did not result in the installation of new machines,

\footnotetext{
${ }^{4}$ Produits forestiers canadien pacifique limitée; analyse socio-économique pour les années financières entre 1986 et 1989, Département de sciences comptables, Université du Québec à Montréal, Juin 1990, 20 p.
} 
but was used to speed up the old machines. The acceleration of the old machines only served to put the problem off for a few years. It is time to look clearly at reality.

\section{Production Costs}

The competetive situation of the Québec forest industry has been seriously deteriorating over the past few years. It seems that this is not due to less control of production costs, as the management of the plants is relatively good. The industries' spokespeople identify three costs which are in part responsible for the erosion of their competitiveness: the cost of fiber, the cost of manpower and the cost of energy. How does this correspond to reality?

It is true that the cost of fiber has increased considerably in the past few years. This increase is due to the growing scarcity of fiber and concern for other forest resources. The change to the era of sophisticated forest tending and growing results from a public which demands sustainable forest management.

It is important to realize that the rising price of fiber is a strong phenomenon world-wide. In Scandinavia the cost of fiber is higher than in Québec. In western Canada and western United States, the price of fiber is rising at a quicker rate than here. It is only in the southern United States that the price of fiber tends to decrease. This lowering of the price is due to the liquidation of pine plantations dating from the 1930's.

It is certain that the industry in the southern United States is a current threat to the Québec industry. However, in the medium term, only the proximity of the markets represents an advantage. The pine plantations will diminish, and public pressure towards multiple use of the forest will be felt there as elsewhere. The cost of fiber will then be similar to those of other regions.

The high cost of wood is a disadvantage to the Québec industry only in the sense that it isn't considered as an economic incentive to abandon a harvesting mentality. For instance, rising costs ensure better prices for owners of rural woodlots, and justify allocation of more resources for socially desired tree-growing efforts in inhabited forests. In this way, the development of a forest legacy is ensured at the same time as a positive image is shown to the world, whereas now Québec and Canada are considered by some to be the Amazon of the North.

While it is true that the large pulp and paper mills are unionized and that the salaries of mill workers are very good, it is important to realize that more and more of the forest operations are carried out by sub-contractors or by small companies, often non-unionized. Within the forest, there has been a deterioration of wages and living conditions for workers. The real problem of high manpower costs is not so much because of high wages, but rather because of the low productivity of obsolete machines. The effects of under investment are again evident.

As for energy costs, the Québec forest industry has historically had a relative advantage because of the abundance of low-cost hydro-electricity. This advantage has diminished recently due to the fact that costs have risen about $25 \%$ since 1987. Looking at the fact that the pulp and paper companies account for a third of industrial sales and $10 \%$ of total sales of electricity, public authorities should consider a policy of granting discounts as they do for aluminum industry.
It is also important to note that certain competitors profit from cogeneration in order to improve their competitiveness. This energy system consists of burning wood wastes to produce steam. This steam is used in the production of pulp and paper, and the excess is used to generate electricity which can be sold to electricity distribution utilities. Perhaps it would be wise to let the Québec industry use this method?

However, Hydro-Québec claims that it does not need the energy that would come from cogeneration. This position of the provincial crown corporation should be questioned as large hydro-electrical projects are provoking growing opposition. This question should be the subject of public debate. Incidentally, the next generic hearing of BAPE (Office of Public Hearing on the Environment), which centers on policy matters rather than specific projects, is on the theme of cogeneration.

\section{Changing Markets}

Québec is a world-wide leader in the production of newsprint. It is often said that Trois-Rivières is, or was, the world capital of newsprint. In fact, Québec is very strong in the production of three forest products: newsprint, market pulp and lumber. However, these three standard products are being traded on commodity markets at slumping prices.

The traditional market for Québec's newsprint is continually deteriorating. Americans read fewer newspapers and the United States tends to be self-sufficient in newsprint. Moreover, the prices of pulp and paper products were disastrous in 1991 and 1992. Besides, exporting these products is a source of impoverishment for Québec. Lumber, for its part, is a product whose value in constant dollars has risen twice as slowly as the consumer price index during the past two decades. Acknowledging that the price for lumber has increased by more than US $\$ 100$ per thousand board feet during 1992 and that price trends for newsprint and market pulp have improved lately should not blur reality. Exporting high-quality wood fiber that has hardly been transformed and letting others provide the value added resembles under-development.

In fact, the forest industries marketing strategy is similar to its investment strategy. All the stakes are put on standard products in a market that is imagined to be captive. One must be blind to continue to waste high quality resources to mass produce products with little added value. The Europeans have understood this. Their forest companies produce specialized products.

As well, European firms are trying to eliminate wholesalers in order to be closer to the customer. Retail companies are looking for associations with the manufacturers of forest products in order to offer, just in time, exactly what the client wants. IKEA is typical of this type of association which makes it possible for the Swedes to come to Canada and sell cheap softwood furniture which could have been produced there.

\section{Victims of Environmentalists}

The forest industry is also currently being attacked by environmentalists who are concerned that the industry is employing bad forestry practices - for example, large-scale clear-cuts, harvest levels that cannot be sustained and use of chemical pesticides. They are also critical of pulp and paper mills which discharge effluents into waterways, use 
chlorine in the bleaching process and discharge furenes and dioxins.

This criticism is being translated into more restrictive government policies. Québec's 1987 forest policy results in higher production costs. As well, new rules will soon be applied by the federal and provincial governments in order to radically reduce the toxicity of the effluent. These rules are challenged by Québec's paper industry because they will involve capital costs of nearly two billion dollars in the short term, without improving productivity.

Outside Canada, the protection of the environment motivates the imposition of non-tariff barriers on Canadian forest products. The obligation that a certain percentage of recycled fibers be included in newsprint to be sold to the United States is an example of such a barrier. The European Economic Community, which is threatening to stop its imports of commercial pulp because of the presence of dioxins and the release of furenes is another example.

\section{What is the Solution?}

After outlining so many problems faced by the Québec forest industry, it seems that there cannot be solutions. But we will try here to identify a few paths which could lead the industry to conserve its role as an economic engine. There are two main aspects in this strategy to end the crisis: an industrial policy and a full employment policy.

\section{An Industrial Policy}

The starting point must be similar to the industrial cluster ideas of Michael Porter ${ }^{5}$ from Harvard University which were popularized in Québec by Gérald Tremblay, Minister of Industry and Commerce. They consist of a strategy identifying markets where Québec has comparative advantages permitting it to penetrate. Forest products have a future, but all of the industry's eggs shouldn't be put in the 2 by 4 , pulp and newsprint basket. As we have seen, these products do not have the greatest future. Production and markets must be diversified at the same time that the number of middlemen is diminished. Manufacturing companies must listen to the consumers' needs and react accordingly. This applies to the forest, as well as to the factories and markets.

It also appears necessary to stop using old machines. This can mean closing those factories which are the least productive and cause the most pollution. What happens after that depends on the ability of business to put into place modern and flexible production units which can respond to the changing needs of the market, and respect the environment.

Modernizing the production processes will require an impressive investment and implies effort by all groups of Québec society, as well as the establishment of a climate of confidence. The elimination of at least a third of the paper machines will lead to the loss of more than 10,000 jobs. With an unemployment rate higher than $13 \%$, this situation is absolutely unacceptable and is a challenge to all of Québec.

\section{A Full Employment Policy}

Rather than leaving each of the actors to manage as best he or she can, it is essential that the political institutions be used to develop a high degree of social cohesion in the search for, and the application of solutions. This condition is necessary in order to transform the stagnation of the forest sector into an occasion to raise the collective wealth. The initiation of this cohesiveness will result in a commitment from the authorities towards a policy of full employment where the economic security of individuals and the improvement of the companies productivity go hand in hand.

In times of crisis, the imagination and investments of industrialists as well as flexibility in tasks and financial concessions on the part of workers are required. However, to have impact, these gestures must be placed in the context of concerted action on the part of interest groups from the regions where factories are located. In the case of a decentralized resource such as the forest, an employment strategy likely to transform the restructuring of the forest industry into an atmosphere for development must necessarily lean on participation of groups which benefit by its existence.

But planning through dialogue and mutual understanding of all stakeholders must not be a swindle where, during a crisis the state hands out subsidies and unions accept the companies demands without anything in return. Planning must be done with open books. There must be no hidden adgendas. The partners must have equal access to all the pertinent information in order to do what they can in hard times and participate in the benefits when time comes to reap the harvest. Otherwise, the losses are nationalized, the profits are privatized and the road is paved to fall back into the rut.

Yes, the forest industry still has a future in Québec, but nothing is guaranteed. It is time for the people who live in the forest regions to take responsibility for their future by making the forest industry their own business. Its restructuring will only be easier, and a bearer of real prosperity.

\footnotetext{
${ }^{5}$ Le Canada à la croisée des chemins: les nouvelles réalités concurrentielles étude réalisée pour le Conseil canadien des chefs d'entreprises et le gouvernement du Canada, Ministère des approvisionnements et services, 1991, 120 p. et The competitive advantage of nations, Michael E. Porter, Free Press, 1990, pp. 1-130.
} 